\title{
Application of Economic Analysis of Air Pollution Reduction Measures
}

\author{
Jasmina Ćetković1, Slobodan Lakić1, Miloš Žarković ${ }^{1 *}$ \\ Gordana Đurovićí, Radoje Vujadinović \\ ${ }^{1}$ Faculty of Economics, University of Montenegro, Jovana Tomaševića 37, 81000 Podgorica, Montenegro \\ ${ }^{2}$ Faculty of Mechanical Engineering, University of Montenegro, Bulevar Džordža Vašingtona bb, \\ 81000 Podgorica, Montenegro
}

Received: 28 February 2020

Accepted: 10 May 2020

\begin{abstract}
This paper presents the economic analysis of air pollution reduction measures in Montenegro. After a brief analysis of the current situation in Montenegro and completed cost estimation of the implementation of these measures, the Low Cost Analysis has been used to determine their cost effectiveness levels. As Low Cost Analysis cannot provide a complete answer on individual eligibility, Cost-Benefit Analysis has been taken into account for calculation of economic performance indicators. Analysis results indicate that the construction of a flue desulphurization system in Thermal Power Plant Pljevlja significantly reduces $\mathrm{SO}_{2}$ emissions. Increasing alternative fuels use, new generations of vehicles and electro mobility in transport measure is only one of the benefits to reduce gas emissions. Similar situation is with the replacement of heating appliances and energy efficiency measures in individual residential buildings, which primarily contributes to energy efficiency. Construction of longdistance heating system measure shows excellent economic results. Prohibition of harvest residues and agricultural waste ignition measure adds to suspended particles $\mathrm{PM}_{2.5}$ emission reduction, cost and benefit ratio is very favorable. It is expected that these measures implementation will certainly contribute to the reduction of pollutant emissions into the air.
\end{abstract}

Keywords: air pollution, economic analysis, low cost analysis, cost-benefit analysis

\section{Introduction}

Achievement of negative externalities mitigation is at the heart of the concept of sustainable development. However, recent researches suggest that a small number of European countries (case of Scandinavian countries) exercise economic growth without the negative impact

*e-mail: milos.zarkovic87@gmail.com on the environment. Notwithstanding the differences in quality across the EU, relevant researches indicate high levels of total pollution in these countries, which implies a need for global harmonization of government emission control policies [1]. In many European countries high economic, social and financial performances are followed by significantly weaker results in case of environmental development. Since sustainable development is a specific economic category, one must bear in mind its three-dimensional 
perspective: economic, social and ecological [2]. At the same time, some research suggests that environmental policies must not impede economic growth and limit the rapid urbanization of the country [3], and countries face demands to optimize production conditions while minimizing pollution and maintaining a healthy and balanced environment. Lately, studies that have correlated life expectancy with the level of air pollution have identified air pollution as the main cause of certain diseases [4-6]. Furthermore, the results of some studies indicate a positive relationship between economic growth and environmental degradation outside Europe [7], which supports the conclusion that this is a global problem. On the other hand, some researches suggest that environmental sustainability practices have a positive impact on innovation in the economy, as well as ecological and social performances [8-10]. On the other hand, many researches are being conducted result in new scientific methods for air quality identification, as well as various techniques for air quality monitoring [11-12].

Researches aimed at analyzing various aspects of improving air quality, by raising the issue of environmental sustainability, have received particular interest and importance. Numerous studies aimed at calculating the economic costs of premature deaths from air pollution have pressured governments to act more ambitiously to reduce pollution [13]. In addition, the primary preoccupation is that activities to improve air quality must be economically sustainable [14-15] and environmentally effective. Examining the literature, it can be concluded that many studies are based on the use of economic appraisal of environmental projects and policies. Furthermore, while observing numerous economic estimation methods for assessing air pollution control programs, the Cost - Benefit Analysis, is widely used [16-20]. Cost-Benefit Analysis has been actualized focusing on monetizing health benefits of pollution control and improving air quality [21].

Our paper aims to present the results of economic analysis of measures to reduce air pollution in Montenegro. In the first step of the economic analysis, the cost of envisaged measures implementation to reduce gas emissions was estimated. The second step is Low Cost Analysis, which is a form of economic analysis that assesses the cost-effectiveness of the proposed measures. In such structure of measures, Low Cost Analysis cannot provide a complete answer on their individual eligibility which led to Cost-Benefit Analysis in the third step.

Research presented in this paper is the result of activities on a project aimed at developing the Measure Program of Air Pollution Control in Montenegro in accordance with the requirements of the EU Directive [22], Guidance for the development of National Air Pollution Control Programs [23] and European Commission Implementing Decision for national air pollution control programs [24], to the extent, in relation to the data availability and documents drafting stage.
For the purpose of this research, official statistics on air quality in Montenegro for the period 2009-2018 were used [25]. Emission reduction estimation through the application of specific measures has been made using available statistics and emission data as well as relevant literature.

\section{Material and Methods}

For the purpose of drafting this strategic document, an appropriate Situation Analysis was made, using SWOT and PESTLE analysis in order to obtain a clearer picture of the current situation and identified resources, opportunities, weaknesses and obstacles for the implementation of measures for reduction of air pollution in Montenegro.

In this regard, the following section provides a brief, indicative analysis of the impact of political, economic, social, technical, legal and environmental factors in Montenegro.

\section{Political Factors}

Montenegro, as a constitutionally declared ecological state, guarantees the right of citizens to a healthy environment. This constitutional right is endangered by air pollution and, accordingly, in accordance with the Constitution, it is the duty of all citizens, and especially of the state, to preserve and improve the environment.

By undertaking international agreements in the field of environmental protection, Montenegro has committed itself to reducing air pollution, especially taking into account the transboundary nature of this phenomenon. With the restoration of independence, in 2006, by succession, Montenegro became a party of the Convention of Long-range Transboundary Air Pollution. In 2011, the Parliament of Montenegro ratified 3 protocols to this Convention - the Protocol on Heavy Metals, the EMEP Protocol and the Gothenburg Protocol. Since 2011 Montenegro was unable to commit itself to significant emission reductions by 2020 , based on the available data on pollutant emissions covered by the Gothenburg Protocol (SOx, NOx, $\mathrm{NH}_{3}, \mathrm{NMVOC}$ ), a proposal to amend the Annex to the Protocol in which are stated targets for Member States' emission reductions, sent by Montenegro to the Secretariat of the LRTAP Convention, have not been accepted. Thus, Montenegro is not a full member of this Protocol. In the meantime, on May 4, 2012, the Gothenburg Protocol was amended, so that emission reduction commitments were extended to beyond 2020 and extended to include reduced suspended particulate emissions. In this way, through the reduction of fine suspended particulate emissions, especially black carbon, as a component of suspended particles, the Gothenburg Protocol synergistically influences to reduce air pollution and mitigate climate change. The revised protocol has so far 
been accepted by 19 members, so it has not yet entered into force.

In addition, by adopting the new National Strategy for Sustainable Development, Montenegro actively participated in meeting the global goals of sustainable development - Agenda 2030. An important political driver in the creation of environmental policy in Montenegro is certainly the process of European integration. Alignment with the new NEC directive is one of the benchmarks for closing Chapter 27 Environment and Climate Change in the EU negotiation process.

\section{Economic Factors}

Since 2006, Montenegro's GDP has almost doubled - from 2,170 million EUR in 2006, up to 4,299 million EUR in 2017. In the same period, the population increased by only $1.1 \%$. The monitored period was marked by efforts to modernize the existing industry, reduced industrial production, the transition to cleaner fuels, and intensified traffic. Investments in improving air quality have increased significantly compared to the period when insufficient attention was paid to this problem, but they are still insufficient to meet established quality standards.

\section{Social Factors}

Montenegro's GDP per capita is about $43 \%$ of the EU average. This certainly results in a slower transition to modern, environmentally friendly vehicles $-32.8 \%$ of vehicles are over 20 years old [26], as well as a slower transition to cleaner fuels and more efficient household heating appliances.

In addition to high electricity prices compared to average incomes, allocating additional funds for heating represents a heavy burden on the budget of households in Montenegro. The fact that more than $10 \%$ of household income is spent on energy indicates energy poverty. Analyses show that firewood is the cheapest energy source, while electricity is at the top of the list and represents one of the most expensive forms of heating energy in Montenegro [27].

Although the impact of air pollution on human health is very serious, quantification of the effects of health pollution on scientific grounds became significant in the 1990s, when long-term practice of air quality monitoring was established with reliable, internationally comparable data and advanced modeling techniques of air quality. At the first global conference on air pollution and health, held in 2018, the World Health Organization (WHO) announced that nine out of ten people on the planet breathe polluted air, and that pollution causes the death of 7 million people a year.

In cooperation with $\mathrm{WHO}$, the assessment of the impact of air pollution on human health in Montenegro was conducted twice in 2016 and 2018. The results of the 2016 analysis showed how much air pollution is affecting quality of health in Montenegro - in Podgorica, Pljevlja and Niksic. More than 250 premature deaths and 140 hospitalizations per year, as well as a number of other health effects, are associated with exposure that exceeds the particulate matter level recommended in the WHO Air Quality Guidelines [28]. More than half of these impacts are related to increased levels of pollution in the winter, mainly due to the combustion of solid fuels due to heating. Based on this estimation, the economic value of early deaths attributable to pollution is approximately 367 million USD annually in these three analyzed cities in Montenegro [29].

During 2018, a similar analysis was done at the regional level. The results showed that air pollution in the Western Balkan countries causes between 15 and $20 \%$ of total mortality and reduces life expectancy by $1.1-1.3$ years. About $75 \%$ of premature deaths, due to exposure to polluted air, are attributable to exposure to increased concentrations of fine suspended particulate $\mathrm{PM}_{2.5}[30]$.

\section{Technical Factors}

Significant technical innovations from 2005 until today, have contributed to the reduction of air pollution in many areas, such as energy, industry, transport. In Montenegro, it is important to mention certain investments in the industry modernization (repair of electro-filter plant in TTP Pljevlja, new arc furnace with dust extraction system in Niksic Steel Mill), as well as the trend of switching to less polluting fuels (use of natural gas in Aluminum Plant Podgorica). However, in line with the requirements of the IE Directive [31], as well as the new legal solutions of Montenegro [32], it is necessary to invest further in order to bring the existing industrial and energy plants in full compliance with the best available techniques.

Applying the EURO standard for vehicles and limit values for pollutant content in liquid fossil fuels has significantly reduced air pollution from the transport sector. By banning the use of motor benzine with leadbased additives in Montenegro in 2011, lead content in PM particles is generally below detection limits. Further improvements are expected in terms of emissions of volatile organic compounds, while e-mobility is becoming a reality and an expansion of the use of electrically powered vehicles is expected in the next ten years [33].

\section{Legal Factors}

The legal framework in the field of air quality is fully in line with EU regulations with the exception of the NEC Directive [22]. It is planned to make necessary amendments to the Law on Air Protection [34] in 2021 in order to fully harmonize with the NEC Directive after the final agreement with the EC on the goals of reducing pollutant emissions in Montenegro, by adopting appropriate by-laws. Following the establishment of 


\begin{tabular}{|c|c|c|c|c|c|c|c|c|c|c|c|c|c|}
\hline \multicolumn{2}{|l|}{ 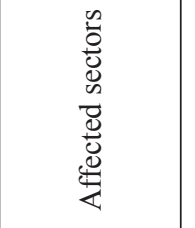 } & \multirow{2}{*}{\multicolumn{2}{|c|}{ 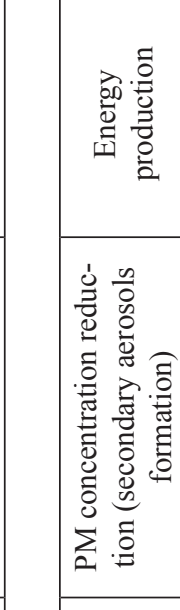 }} & \multirow{2}{*}{\multicolumn{2}{|c|}{ 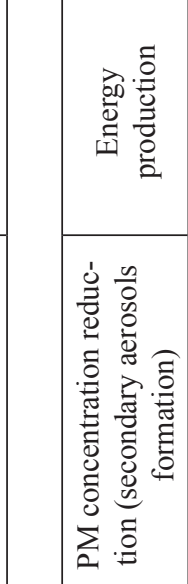 }} & & 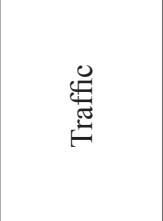 & & \multicolumn{3}{|c|}{ 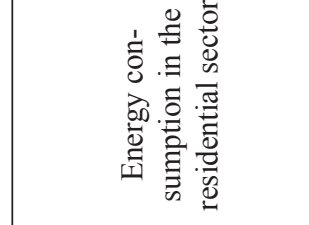 } & & \multirow{2}{*}{ 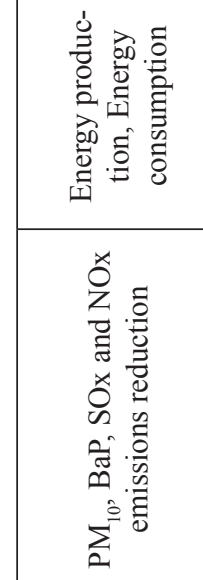 } \\
\hline 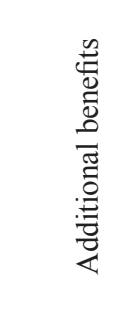 & & & & & & & 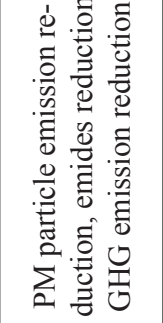 & & & 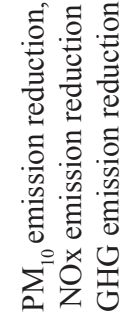 & & & \\
\hline 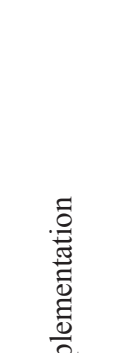 & 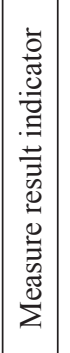 & & 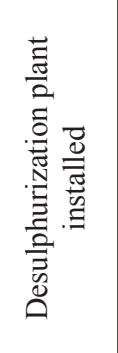 & & 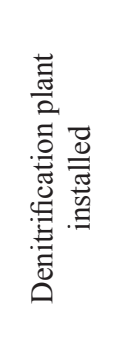 & & 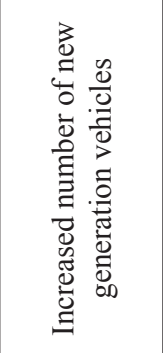 & & & 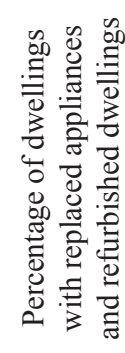 & & & 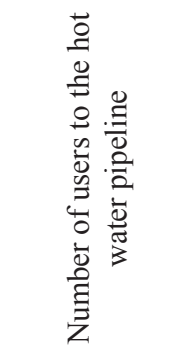 \\
\hline 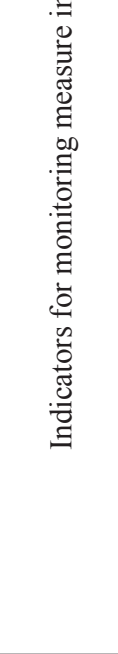 & 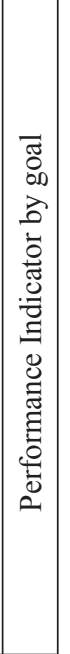 & $\theta^{2}$ & 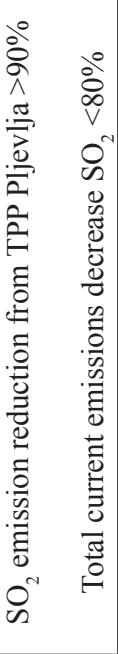 & $\begin{array}{l}\tilde{z} \\
\check{z}\end{array}$ & 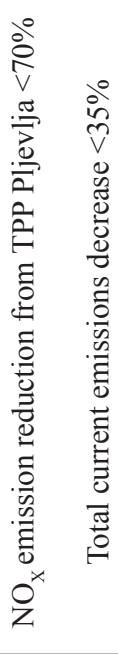 & ố & 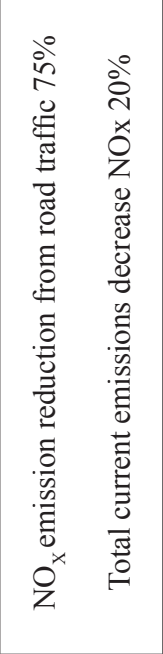 & $\left|\begin{array}{c}0 \\
0 \\
y \\
\sum_{i j}^{i j} \\
e^{i f}\end{array}\right|$ & 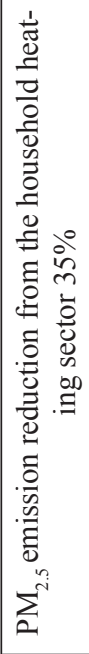 & 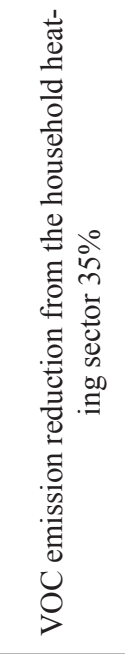 & 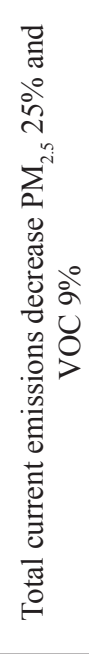 & 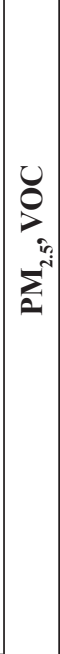 & 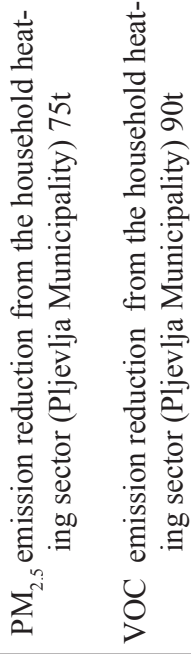 \\
\hline 言.$\overline{0}$ & $\overrightarrow{7}$ & & ֶิ & & ֶิ & & ڤิे & & & ते & & & હે \\
\hline$\sum^{\infty} \overline{\frac{2}{c}} \frac{\Xi}{2}$ & 悫 & & ڤ్ & & ڤે & & ๙ัญ & & & त్రి & & & त्రి \\
\hline 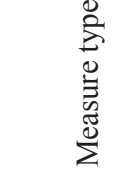 & & & 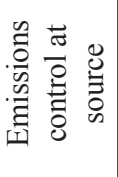 & & 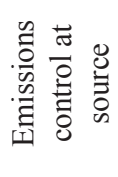 & & 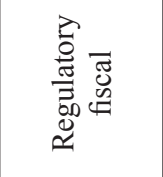 & & & 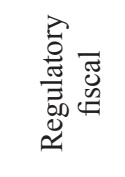 & & & 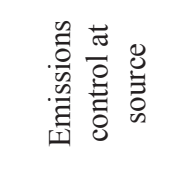 \\
\hline 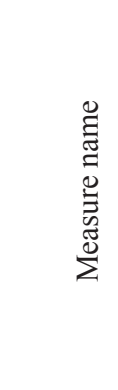 & & & 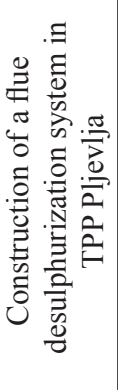 & & 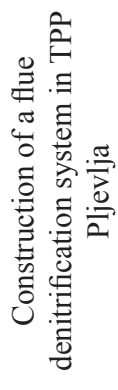 & & 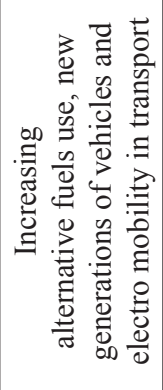 & & & 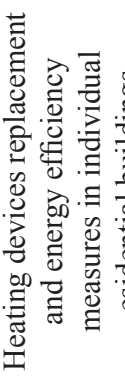 & & & 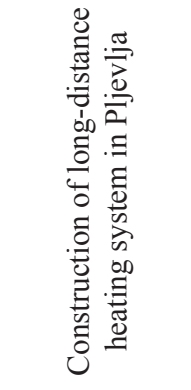 \\
\hline
\end{tabular}




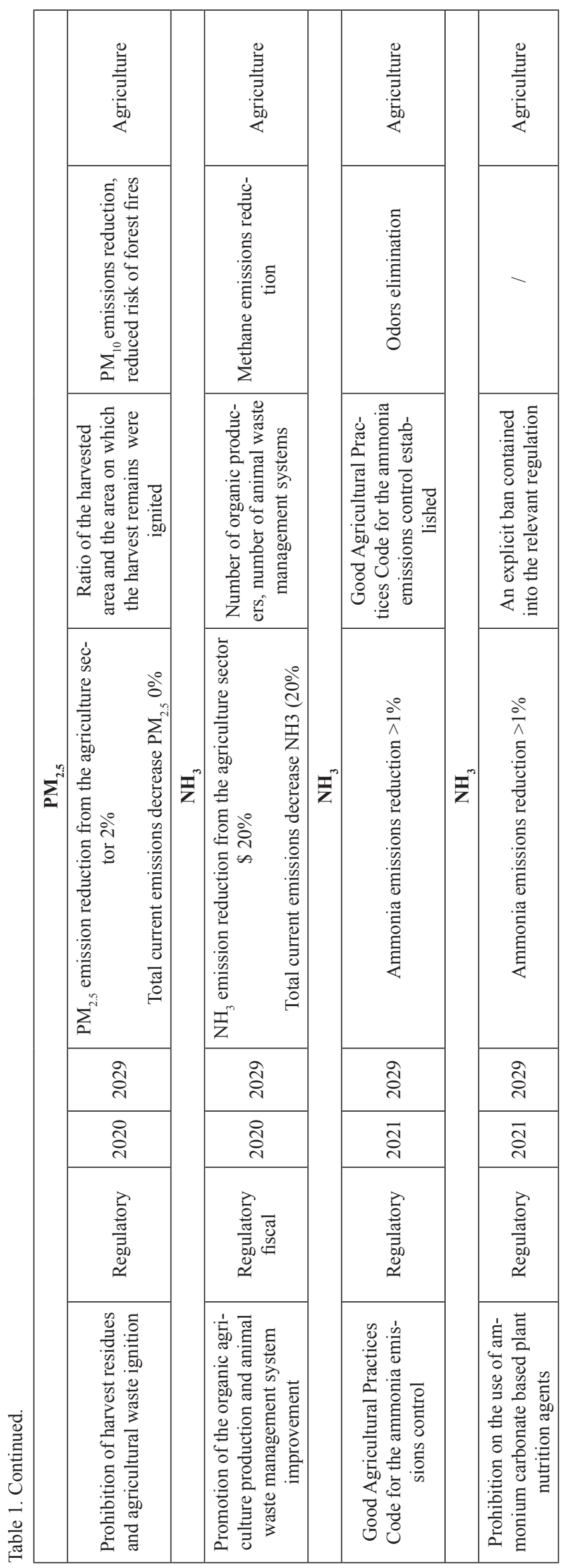

obligations to reduce pollutant emissions covered by the NEC Directive, Montenegro will ratify the updated Gothenburg Protocol to the LRTAP Convention.

\section{Ecological Factors}

Based on the air quality data analysis for the period 2009-2018 the positive trends, i.e. decreases in concentrations of certain pollutants in the air at numerous measuring points are evident. On the other hand, the data on pollutant emissions into the air are not comparable to them, first of all, there is no inventory data for the whole observed period.

\section{Proposed Measures to Reduce Air Pollution in Montenegro in the Period 2020-2029}

The main commitments in establishing measures to reduce emissions and improve air quality in Montenegro, for the purpose of developing the Program of Measures for Air Pollution Control in Montenegro were:

- prioritize measures in the sectors that contribute most to total emissions at national level;

- ensure the continuation of the measures implementation defined in the previous action plans and the period beyond 2020, with additional improvements;

- establish stronger synergy of policies and measures to reduce pollutant emissions and improve air quality with policies and measures to reduce greenhouse effects, increase the share of renewable energy sources and energy efficiency.

Table 1 provides an overview of key measures with an estimated effect quantification of the measures implementation to reduce emissions and improve air quality in Montenegro.

\section{Results and Discussion}

The economic analysis of the implementation of envisaged measures for the air pollution reduction in Montenegro was made in accordance with the recommendations from the official European documents and various study documents, as well as the authors' previous experience in the preparation of economic and financial analysis.

Within the first part of the economic analysis, the cost of implementing measures to reduce gas emissions was estimated. For this purpose, as will be noted, various relevant sources have been used, including expert evaluations of consultants.

Second part of the economic analysis contains Low Cost Analysis, which was done according to the recommendations of the relevant European documents [35] and is economic analysis form that assesses cost-effectiveness level of the proposed measures to determine the investments needed to reduce one ton 
of specific gas emissions for each of the proposed measures.

Given that Low Cost Analysis cannot provide a complete response to individual eligibility with such a structure of measures, Cost-Benefit Analysis was used as third part of economic analysis. This method is recommended when key direct benefits and direct costs can be monetized, or expressed in monetary terms. With this method, projected reductions in gas emissions are designed and quantified. The value represents the ratio between estimated application costs and applying discounting process (reducing future values through a discount factor to present value) and projected gas reductions. The final analysis result is certain economic indicators calculation. On this basis, a conclusion on the cost-effectiveness of the individual measure implementation and their relationship can be drawn.

\section{Results of Economic Analysis}

This part of the paper presents individual results of the economic analysis, namely:

- Estimation of the implementation costs of the envisaged emission reduction measures,

- Low Cost Analysis results by certain measure and

- Cost-Benefit Analysis results by certain measure.

\section{Estimation of Implementation Costs of the Envisaged Measures for Reduction of Air Pollution in Montenegro}

Costs estimation was done individually, according to each pre-planned measure for reduction of air pollution in Montenegro. For this purpose, all available and accessible official documentation, Monstat statistics, relevant market data, data obtained directly from parties involved in individual projects, as well as expert assessments of consultants, were used.

\section{Estimation of the Construction Costs of a Flue Desulphurization System in TTP Pljevlja}

The Electric Power Industry of Montenegro has been in the process of implementing the ecological reconstruction project of the TTP Pljevlja for some time now. The entire ecological reconstruction project involves the construction of a desulphurization system, a denitrification system, an improvement of the operation of the filter plant, as well as the construction of wastewater treatment system. Ecological reconstruction works should take place in the period 2019-2021 after which the life expectancy of TTP Pljevlja will be extended by 20 years.

The total value of the tender for the ecological reconstruction of the TTP Pljevlja is estimated at EUR 45 million without VAT, or EUR 54.45 million with VAT. It was found that the construction costs of a flue desulphurization system in TTP Pljevlja were calculated in the amount of EUR 20 million without VAT, or EUR 24.2 million with VAT.

\section{Estimation of Construction Costs of Flue Gas Denitrification System in TPP Pljevlja}

During the preparation of the reconstruction budget for the needs of the Tender, based on the official data obtained from the National Energy Company of Montenegro, it was determined that the flue gas denitrification system costs in PTP Pljevlja were calculated in the amount of EUR 9 million excluding VAT, i.e. EUR 10.9 million with VAT.

\section{Estimation of Increased Use of the Alternative Fuels, New Vehicle Generations and Electromobility Costs in Transport}

In estimating these costs, the following assumptions were taken into account:

Table 2. Age structure and vehicle type structure in Montenegro in 2018.

\begin{tabular}{|c|c|c|c|c|c|c|}
\hline Production year & Motorcycles & Passenger cars & Cargo & Busses & Total & Percent \\
\hline Until 1980 & 14 & 223 & 251 & 1 & 489 & $0.2 \%$ \\
\hline $1980-1990$ & 70 & 10,211 & 1,580 & 59 & 11,920 & $5.1 \%$ \\
\hline $1990-1995$ & 83 & 19,522 & 1,464 & 119 & 21,188 & $9.0 \%$ \\
\hline $1995-2000$ & 144 & 24,833 & 1,927 & 186 & 27,090 & $11.5 \%$ \\
\hline $2000-2005$ & 603 & 62,391 & 4,648 & 459 & 68,101 & $28.9 \%$ \\
\hline $2005-2010$ & 2,298 & 50,146 & 6,391 & 463 & 59,298 & $25.2 \%$ \\
\hline $2010-2015$ & 1,123 & 26,715 & 3,070 & 105 & 31,013 & $13.2 \%$ \\
\hline from 2015 & 1,320 & 12,412 & 2,487 & 67 & 16,286 & $6.9 \%$ \\
\hline Total & 5,655 & 206,453 & 21,818 & 1,459 & 235,385 & $100.0 \%$ \\
\hline Vehicle type ratio & $2.4 \%$ & $87.7 \%$ & $9.3 \%$ & $0.6 \%$ & $100.0 \%$ & \\
\hline
\end{tabular}


Table 3. Vehicle structure by propulsion energy type in Montenegro.

\begin{tabular}{|c|c|c|c|c|}
\hline \multirow{2}{*}{$\begin{array}{c}\text { Propulsion energy } \\
\text { type }\end{array}$} & \multicolumn{2}{|c|}{ Year } & \multicolumn{2}{c|}{ Ratio } \\
\cline { 2 - 5 } & 2017 & 2018 & 2017 & 2018 \\
\hline Euro super 95 & 55,349 & 55,081 & $25.5 \%$ & $23.7 \%$ \\
\hline Euro super 98 & 459 & 462 & $0.2 \%$ & $0.2 \%$ \\
\hline Euro diesel & 152,867 & 168,821 & $70.5 \%$ & $72.6 \%$ \\
\hline Mixed & 6 & 13 & $0.0 \%$ & $0.0 \%$ \\
\hline Auto gas & 8,054 & 8,075 & $3.7 \%$ & $3.5 \%$ \\
\hline Electricity & 49 & 106 & $0.0 \%$ & $0.0 \%$ \\
\hline Total & 216,784 & 232,558 & $100.0 \%$ & $100.0 \%$ \\
\hline
\end{tabular}

- introduction of new hybrid cars in the period 2020-2029;

- reduction of the number of diesel vehicles in the period 2020-2029;

- increase in the number of gas-powered vehicles in the period 2020-2026;

- disbursement of old cars in the period 2020-2029;

- introduction of new electric cars in the period 20202029.

Official statistics [36] show that in 2018, a total of 235,385 vehicles were registered in Montenegro, representing an increase of $7.3 \%$ compared to 2017 . In the same year, the number of vehicles registered for the first time was 25,099, which is about $14 \%$ more compared to 2017.

Table 2 shows the vehicle age structure combined with the main vehicle category structure in Montenegro adjusted to the needs of this analysis within longer time intervals.

Table 3 provides vehicle structure by driving energy type in Montenegro.

Based on the presented data, it can be concluded that diesel consumption has a dominant share with about $73 \%$ of the total number of vehicles. Benzine vehicles accounted for $24 \%$ and auto gas for $3.5 \%$. The involvement of electric and hybrid vehicles is negligible.

According to the latest research [33] in Montenegro in 2035 the total number of passenger cars is expected to increase to around 284,000 (in the real scenario), or about 329,000 passenger cars (in the optimistic scenario). In the same period, the expected number of registered electric cars is around 60,000 in the real scenario, or about 96,000 in the optimistic scenario. For the purposes of this analysis, real scenario data for the period 2020-2029 were used, according to which, in 2029 , the total number of passenger cars is projected to increase to 246,695 , of which the number of first registering cars is 26,881 and the number of new cars is 5,376 [33]. According to this scenario, the number of diesel cars is constantly decreasing over the observed period, the number of benzine-powered cars, hybrid cars (for which there are no statistics on the number) and electric cars is increasing, while the number of passenger cars powered by LPG is approximately constant.

After making certain assumptions, a projection of the vehicle numbers in Montenegro for the period 20202029 is shown in Table 4.

For the purpose of necessary investment determination, adequate estimation of the increasing use of alternative fuels, new types of fuels and electromobility costs in transport, an analysis has been conducted for the new vehicles procurement market in Montenegro - both current with conventional propulsion and future vehicles, i.e. electric and hybrid vehicles.

Based on the projected number of vehicles in Montenegro in the period 2020-2029 (Table 4), as well as market analysis of new car prices, a projection of the purchasing vehicles cost using alternative fuels - hybrid and electric vehicles is presented in Table 5.

Table 4. Projection of the vehicle numbers in Montenegro for the period 2020-2029.

\begin{tabular}{|c|c|c|c|c|c|c|c|c|c|c|}
\hline Vehicle type & 2020 & 2021 & 2022 & 2023 & 2024 & 2025 & 2026 & 2027 & 2028 & 2029 \\
\hline Diesel & 14,000 & 13,000 & 12,000 & 11,000 & 10,000 & 9,000 & 8,000 & 6,500 & 4,500 & 3,500 \\
\hline Benzine & 7,200 & 8,000 & 8,500 & 9,000 & 9,500 & 10,000 & 10,500 & 10,500 & 10,500 & 10,000 \\
\hline Hybrid & 400 & 500 & 1,000 & 1,500 & 2,000 & 2,500 & 3,000 & 3,500 & 4,000 & 4,500 \\
\hline Electric & 200 & 350 & 550 & 900 & 1,200 & 1,419 & 2,255 & 3,765 & 5,944 & 8,881 \\
\hline $\begin{array}{c}\text { Total of first time } \\
\text { registered }\end{array}$ & 21,800 & 21,850 & 22,050 & 22,400 & 22,700 & 22,919 & 23,755 & 24,265 & 24,944 & 26,881 \\
\hline $\begin{array}{c}\text { Number of new passenger } \\
\text { vehicles }\end{array}$ & 3,379 & 3,496 & 3,638 & 3,808 & 3,973 & 4,125 & 4,395 & 4,610 & 4,864 & 5,376 \\
\hline $\begin{array}{c}\text { Total number of passenger } \\
\text { vehicles }\end{array}$ & 206,500 & 208,500 & 210,500 & 212,500 & 214,500 & 216,500 & 225,500 & 235,313 & 237,760 & 246,695 \\
\hline $\begin{array}{c}\text { Dismantled passenger } \\
\text { vehicles }\end{array}$ & 8,950 & 9,950 & 10,950 & 11,950 & 12,950 & 13,950 & 14,950 & 15,950 & 16,950 & 17,950 \\
\hline
\end{tabular}


Table 5. Projection of procurement costs of increased use of the alternative fuels, new vehicle generations and electromobility in the period 2020-2029.

\begin{tabular}{|c|c|c|c|c|c|}
\hline Vehicle type & 2020 & 2021 & 2022 & 2023 & 2024 \\
\hline Hybrid vehicles & $6,634,000$ & $8,292,500$ & $16,585,000$ & $24,877,500$ & $33,170,000$ \\
\hline Electric vehicles & $3,197,000$ & $5,594,750$ & $8,791,750$ & $14,386,500$ & $19,182,000$ \\
\hline Total & $9,831,000$ & $13,887,250$ & $25,376,750$ & $39,264,000$ & $52,352,000$ \\
\hline Vehicle type & 2025 & 2026 & 2027 & 2028 & 2029 \\
\hline Hybrid vehicles & $41,462,500$ & $46,650,288$ & $48,932,384$ & $51,628,442$ & $57,063,014$ \\
\hline Electric vehicles & $22,682,715$ & $25,291,467$ & $26,528,706$ & $27,990,374$ & $30,936,730$ \\
\hline Total & $64,145,215$ & $71,941,755$ & $75,461,090$ & $79,618,816$ & $87,999,744$ \\
\hline
\end{tabular}

Related to Table 5, we conclude that the cost of implementing this measure ranges from EUR 9.8 million in 2020 to EUR 88 million in 2029, representing a total of EUR 519.9 million in the period 2020-2029.

\section{Cost Estimation for Heating Devices Replacement and Energy Efficiency Measures in Individual Residential Buildings}

According to official statistics, 245,734 dwellings were registered in Montenegro, of which 186,498 were occupied for the purpose of housing only [33]. Of this number, $86.7 \%$ are owned by physical persons, of which about $70 \%$ is wood-fired and these are mostly individual residential buildings. Based on the analysis of the current situation, the assumption is made that this measure has already been applied to about $25 \%$ of buildings. Thus, there are about 84,890 individual residential buildings remaining, with an average size of $72.3 \mathrm{~m}^{2}$, or a total residential area of 6.14 million $\mathrm{m}^{2}$.

After determining the number of dwellings to which the mentioned measures apply in the period 2020-2029, it was necessary to determine the average unit implementation costs for average size individual dwelling. This measure consists of 3 components: installation of energy efficient joinery, installation of thermal insulation on the facade walls and replacement of heating devices.

In relation to previous calculations, implementation cost of this measure is estimated to be EUR 4,375 per individual dwelling, or a total of EUR 371.4 million for 84,890 reconstruction projects planned for 2029 .

\section{Costs Estimation of Long-Distance Heating System Construction in Pljevlja}

Within the long-distance heating system construction project in Pljevlja municipality, it is necessary to provide a central source of thermal energy, as well as the construction of a district heating network and infrastructure for connecting households to the network. The total necessary investment amount exists only at the estimate level and one of them indicates to allocate EUR 23 million for the project realization [37]

\section{Cost Estimation for Prohibition of Harvest Residues and Agricultural Waste Ignition}

This measure was recommended by the NEC Directive, the Law on Waste Management in Montenegro [38], as well as with the Code of Good Agricultural Practice in Montenegro (GAP). It is primarily of a regulatory nature, and therefore does not require particular significant investment, but rather an adequate organization for optimal implementation. This measure involves adequate information and a promotional campaign in order to become aware of the regulations and to motivate their application to appropriate penal provisions in case of their violation. There are no specific data sources for these measures. Costs assessment of implementing this measure included certain data on implementation of similar operational and organizational measures. They envisage activities that can be compared with this measure in terms of scope and implementation. For the implementation of this measure an amount of EUR 0.5 million is foreseen until 2030, that is, linearly EUR 50 thousand a year, since these activities do not represent a one-off but a continuous activity.

\section{Cost Estimation for Promotion of the Organic Agriculture Production and Animal Waste Management System}

Two separate activity categories are present with this measure. The first is to promote organic production and the second is to improve the animal waste management system. According to official data [39], funds for the current year are estimated at EUR 400 thousand for the first activity and EUR 130 thousand for the second activity. As stated by official documents [40], investments in agri-environment measures by the EU through IPARD funds are foreseen in the period 2018-2020 following EUR 700 thousand in 2018, EUR 1.36 million in 2019 and EUR 1.44 million in 2020. 
Table 6. Recapitulation of cost emission reductions over the period 2020-2029 in Montenegro.

\begin{tabular}{|c|c|}
\hline Description of costs & Amount \\
\hline Costs of construction of a flue desulphurization system in TPP Pljevlja & 24.2 mil. EUR \\
\hline Costs of construction of a flue denitrification system in TPP Pljevlja & 10.9 mil. EUR \\
\hline Costs of increased use of the alternative fuels, new vehicle generations and electromobility in transport & 519.9 mil. EUR \\
\hline Costs of heating devices replacement and energy efficiency measures in individual residential buildings & 371.4 mil. EUR \\
\hline Costs of construction of long-distance heating system in Pljevlja & 23 mil. EUR \\
\hline Costs of prohibition of harvest residues and agricultural waste ignition & 0.5 mil. EUR \\
\hline Costs of promotion of the organic agriculture production and animal waste management system improvement & 10 mil. EUR \\
\hline Costs of good agricultural practices code for the ammonia emissions control & 0.5 mil. EUR \\
\hline Costs of prohibition on the use of ammonium carbonate based plant nutrition agents & 0.5 mil. EUR \\
\hline Total & 960.9 mil. EUR \\
\hline
\end{tabular}

The implementation of this measure with the support of IPARD funds has not yet started with anticipated funds amounting to EUR 0.48 million in 2020 and continued funding in the following years. Based on the above assumptions, it can be concluded that this measure costs are estimated at EUR 1 million per year, i.e. EUR 10 million for the period 2020-2029.

\section{Cost Estimation of Good Agricultural Practices Code for the Ammonia Emissions Control}

Like the previous, this measure is mandatory as required by the NEC Directive, although it declares that member states may exempt small and micro farms from the application of this measure, where possible

Table 7. Estimation of the annual amount of emission reductions after implementation of the envisaged measures.

\begin{tabular}{|c|c|c|c|c|}
\hline Measure & $\begin{array}{l}\text { Gas type whose } \\
\text { emission is affected } \\
\text { by the proposed } \\
\text { measure }\end{array}$ & $\begin{array}{l}\text { Emission } \\
\text { reductions } \\
\text { from baseline } \\
2005\end{array}$ & $\begin{array}{l}\text { Annual amount of } \\
\text { emission reduction } \\
\text { in the base year } \\
2005 \text { (tons) }\end{array}$ & $\begin{array}{l}\text { Annual amount of } \\
\text { emission reduction } \\
\text { after proposed } \\
\text { measure implementa- } \\
\text { tion (tons) }\end{array}$ \\
\hline $\begin{array}{c}\text { Construction of a flue desulphurization } \\
\text { system in TPP Pljevlja }\end{array}$ & $\mathrm{SO}_{2}$ & $50 \%$ & 12,500 & 6,250 \\
\hline $\begin{array}{c}\text { Construction of a flue denitrification } \\
\text { system in TPP Pljevlja }\end{array}$ & $\mathrm{NO}_{\mathrm{x}}$ & $10 \%$ & 7,500 & 750 \\
\hline $\begin{array}{c}\text { Increase of the alternative fuels use, new } \\
\text { vehicle generations and electromobility in } \\
\text { transport }\end{array}$ & NOx & $5 \%$ & 7,500 & 375 \\
\hline \multirow{2}{*}{$\begin{array}{l}\text { Heating devices replacement and energy } \\
\text { efficiency measures in individual } \\
\text { residential buildings }\end{array}$} & $\mathrm{PM}_{2.5}$ & $25 \%$ & 4,600 & 1,150 \\
\hline & VOC & $9 \%$ & 8,380 & 754 \\
\hline \multirow{4}{*}{$\begin{array}{l}\text { Construction of long-distance heating } \\
\text { system in Pljevlja }\end{array}$} & $\mathrm{PM}_{2.5}$ & & & 75 \\
\hline & VOC & & & 90 \\
\hline & $\mathrm{SO}_{2}$ & & & 168 \\
\hline & VOC & & & 21 \\
\hline $\begin{array}{l}\text { Prohibition of harvest residues and } \\
\text { agricultural waste ignition }\end{array}$ & $\mathrm{PM}_{2.5}$ & $0.33 \%$ & 4,600 & 15 \\
\hline $\begin{array}{l}\text { Promotion of the organic agriculture } \\
\text { production and animal waste management } \\
\text { system improvement }\end{array}$ & $\mathrm{NH}_{3}$ & $2 \%$ & 3,710 & 74 \\
\hline $\begin{array}{l}\text { Good Agricultural Practices Code for the } \\
\text { ammonia emissions control }\end{array}$ & $\mathrm{NH}_{3}$ & $0.33 \%$ & 3,710 & 12 \\
\hline $\begin{array}{l}\text { Prohibition on the use of ammonium } \\
\text { carbonate based plant nutrition agents }\end{array}$ & $\mathrm{NH}_{3}$ & $0.33 \%$ & 3,710 & 12 \\
\hline
\end{tabular}


and applicable in the context of fulfilling the emission reduction obligation. As a measure that is primarily of a regulatory nature, this measure implies the adoption of appropriate regulations and documents, information and promotion campaigns in order to get acquainted and motivated for the implementation, as well as continuous education. Considering the fact that these activities are not a one-off, but continuous, a total amount of EUR 0.5 million is foreseen for the implementation of this measure for the period 2020-2029.

\section{Prohibition of the Plant Nutrition Use Based on Ammonium Carbonate Cost Estimation}

With this measure implementation, it is expected adoption of appropriate laws and regulations, information and promotion campaign, penalties application for non-compliance and continuing education. As there are no specific data sources, certain data on similar operational and organizational measure implementation were used to assess needed investments. The Ttotal amount of EUR 0.5 million is foreseen for the implementation of this measure for the period 2020-2029.

Table 6 shows recapitulation of cost emission reductions over the period 2020-2029 in Montenegro.

\section{Results of Low Cost Analysis}

Low Cost Analysis implied the preliminary determination of implementation measure cost (given in the previous section), as well as the projected nominal emission reduction (estimated in tons) for each measure separately. These values are used to calculate the

Table 8. Projection of annual emission reductions by envisaged measures (in tons) for period 2020-2029

\begin{tabular}{|c|c|c|c|c|c|c|c|c|c|c|c|c|c|}
\hline & Measure & $\begin{array}{l}\text { Gas } \\
\text { type }\end{array}$ & 2020 & 2021 & 2022 & 2023 & 2024 & 2025 & 2026 & 2027 & 2028 & 2029 & $\begin{array}{c}\text { Total } \\
2020-2029 \text { tons }\end{array}$ \\
\hline 1 & $\begin{array}{c}\text { Construction of a flue } \\
\text { desulphurization system } \\
\text { in TTP Pljevlja }\end{array}$ & $\mathrm{SO}_{2}$ & \multicolumn{4}{|c|}{ Investments } & 6,250 & 6,250 & 6,250 & 6,250 & 6,250 & 6,250 & 37,500 \\
\hline 2 & $\begin{array}{c}\text { Construction of a flue } \\
\text { denitrification system in } \\
\text { TTP Pljevlja }\end{array}$ & $\mathrm{NO}_{\mathrm{x}}$ & \multicolumn{4}{|c|}{ Investments } & 750 & 750 & 750 & 750 & 750 & 750 & 4,500 \\
\hline 3 & $\begin{array}{l}\text { Increase of the alter- } \\
\text { native fuels use, new } \\
\text { vehicle generations } \\
\text { and electromobility in } \\
\text { transport }\end{array}$ & $\mathrm{NO}_{x}$ & 0 & 38 & 75 & 113 & 150 & 188 & 225 & 263 & 300 & 338 & 1,688 \\
\hline \multirow[b]{2}{*}{4} & \multirow{2}{*}{$\begin{array}{l}\text { Heating devices re- } \\
\text { placement and energy } \\
\text { efficiency measures in } \\
\text { individual residential } \\
\text { buildings }\end{array}$} & $\mathrm{PM}_{2.5}$ & 0 & 115 & 230 & 345 & 460 & 575 & 690 & 805 & 920 & 1,035 & 5,175 \\
\hline & & VOC & 0 & 75 & 151 & 226 & 302 & 377 & 453 & 528 & 603 & 679 & 3,394 \\
\hline \multirow{4}{*}{5} & \multirow{4}{*}{$\begin{array}{l}\text { Construction of long- } \\
\text { distance heating system } \\
\text { in Pljevlja }\end{array}$} & $\mathrm{PM}_{2.5}$ & \multirow{4}{*}{\multicolumn{4}{|c|}{ Investments }} & 75 & 75 & 75 & 75 & 75 & 75 & 450 \\
\hline & & VOC & & & & & 90 & 90 & 90 & 90 & 90 & 90 & 540 \\
\hline & & $\mathrm{SO}_{2}$ & & & & & 168 & 168 & 168 & 168 & 168 & 168 & 1,008 \\
\hline & & $\mathrm{NO}_{x}$ & & & & & 21 & 21 & 21 & 21 & 21 & 21 & 126 \\
\hline 6 & $\begin{array}{c}\text { Prohibition of harvest } \\
\text { residues and agricultural } \\
\text { waste ignition }\end{array}$ & $\mathrm{PM}_{25}$ & 0 & 2 & 3 & 5 & 6 & 8 & 9 & 11 & 12 & 14 & 68 \\
\hline 7 & $\begin{array}{l}\text { Promotion of the organic } \\
\text { agriculture production } \\
\text { and animal waste man- } \\
\text { agement system im- } \\
\text { provement }\end{array}$ & $\mathrm{NH}_{3}$ & 0 & 7 & 15 & 22 & 30 & 37 & 45 & 52 & 59 & 67 & 334 \\
\hline 8 & $\begin{array}{l}\text { Good Agricultural Prac- } \\
\text { tices Code for the ammo- } \\
\text { nia emissions control }\end{array}$ & $\mathrm{NH}_{3}$ & 0 & 1 & 2 & 4 & 5 & 6 & 7 & 9 & 10 & 11 & 55 \\
\hline 9 & $\begin{array}{c}\text { Prohibition on the use } \\
\text { of ammonium carbon- } \\
\text { ate based plant nutrition } \\
\text { agents }\end{array}$ & $\mathrm{NH}_{3}$ & 0 & 1 & 2 & 4 & 5 & 6 & 7 & 9 & 10 & 11 & 55 \\
\hline
\end{tabular}


investment cost-effectiveness, i.e. the ratio of individual measures investment and emission reductions amount, regardless of the gas type.

Gas emissions reduction projections in the period 2020-2029 have been calculated taking into account previous analyzes and considerations. In the projections, it has been taken into account that individual measures require complete implementation to begin to produce emission reduction effects, while certain measures imply continued implementation over the next ten-year period, with the emission reductions effects gradually increasing.

Table 7 shows the estimated annual emission reductions after implementation of the envisaged measures.

Based on the projections of annual emission reductions, total emission reductions for the whole period have been determined, as shown in Table 8 .

In a further analysis step, investment costeffectiveness per ton of emission reductions was determined by placing in the ratio the cost of implementation of the measures and total emission reduction quantities, which is shown in Fig. 1.

According to the Low Cost Analysis results, it is clear that the construction of a flue desulphurization system in TTP Pljevlja achieves the best effects in terms of investment cost-effectiveness in relation to the total gas emission reduction amount as case with $\mathrm{SO}_{2}$. This is the expected result, as TTP Pljevlja is the largest single pollutant with the aforementioned gas which will be significantly reduced with the implementation of this measure. With this, the best Low Cost Analysis results are achieved with the installation of the construction of a flue denitrification system in TTP Pljevlja. Observed from the cost-effectiveness point of view, three regulatory measures follow, concluding with a measure of increasing use of alternative fuels, new generations of vehicles and electromobility in transport.

Obtained results confirm that Low Cost Analysis is not the best method for considering investment cost-effectiveness in the case of measures with extremely large amount of investment differences. These regulatory measures contribute to small overall emission reduction, but implementation costs are low.

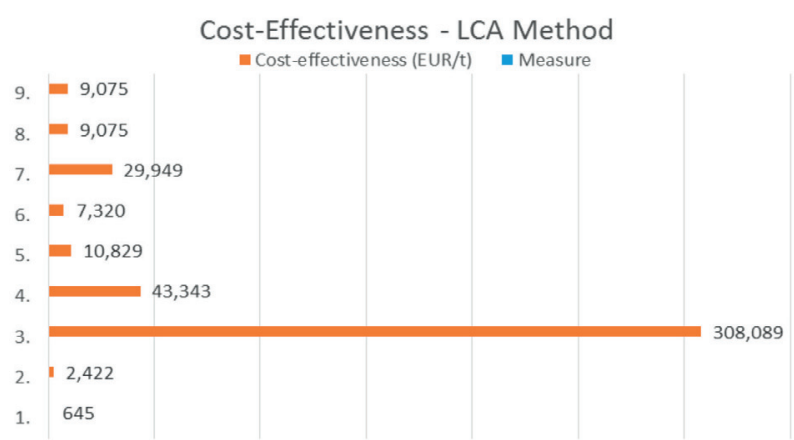

Fig. 1. Investment cost-effectiveness level by measure (EUR/ ton) - Low Cost Analysis results.
On the other hand, the increase of the alternative fuels use contributes to more significant reductions in the gas emissions amount. However, this requires extremely large investments and their results are worse by this analysis criteria. Implementing effect of this measure will not only be gas emissions reduction, but primarily increasing energy efficiency.

That is why, despite the certain Low Cost Analysis advantages, Cost-Benefit Analysis was further developed as it assigns monetary values to the effects of gas reduction for each of the proposed measures and calculates the Net Present Value indicator. The analysis allows better investment cost-effectiveness view in the planned measures and their comparison.

\section{Results of Cost-Benefit Analysis}

The appropriate methodology [35] defines a way of considering costs and benefits in the process anticipated measures evaluation, which involves comparing the costs and benefits for each identified measure. After identifying the necessary investments for each measure, as well as the estimated emissions reductions by measures, it was necessary to determine the benefits per ton of reduced pollutant and make appropriate projections of the effects. Finally, we discounted net effects for each measure and calculated the Net Present Value indicator in order to assess the overall benefit of each measure. The advantage of this approach is that it allows the selection of measures that bring the greatest economic benefits, while the disadvantage is that the benefits of individual measures cover only part of the positive effects that individual measures cause.

Air pollution is increasing in Europe and the world, posing enormous risks to human health and life. These adverse effects cause large financial allocations for health care services, but above all there are huge negative effects due to premature death cases (based on the Value of Statistic life principle). Therefore, investments in environmental pollution reduction, result in the cost savings and these economic savings can be quantified.

Since environmental investments directly cause emission reductions of certain gas types, the most acceptable method for economic analysis of these investments is to determine the "damage" caused by certain gases, per unit of emission, usually in tons. This is not a simple task, since it is necessary to clearly establish the correlation between the emission of individual gases, the adverse health effects they cause and the values of health services for these purposes, as well as the statistical values of life.

In Montenegro, but also in most developed EU countries, no individual studies have been carried out on these values, but there are some relevant studies [41-42] that have adequately addressed this issue at EU level, determining the values of gas emissions damages. These studies and analyzes have examined in detail the effects of air pollution on human health and correlated 
Table 9. Unit values of pollution costs by gas type (EUR/t).

\begin{tabular}{|c|c|c|c|}
\hline Gas type & CAFE (2010) & HEC-Ricardo, AEA (2014) & Average value \\
\hline $\mathrm{NH}_{3}$ & 31,000 & 48,300 & 39,690 \\
\hline $\mathrm{NO}_{\mathrm{x}}$ & 12,000 & 10,640 & 11,320 \\
\hline $\mathrm{PM}$ & 87,000 & 99,160 & 93,080 \\
\hline $\mathrm{SO}_{2}$ & 18,000 & 10,240 & 14,120 \\
\hline $\mathrm{VOC}$ & 3,000 & 1,566 & 2,283 \\
\hline
\end{tabular}

Table 10. Unit values of pollution costs by gas type for Montenegro (EUR/t).

\begin{tabular}{|c|c|}
\hline Gas type & Unit value \\
\hline $\mathrm{NH}_{3}$ & 10,545 \\
\hline $\mathrm{NO}_{\mathrm{x}}$ & 3,011 \\
\hline $\mathrm{PM}$ & 24,755 \\
\hline $\mathrm{SO}_{2}$ & 3,755 \\
\hline $\mathrm{VOC}$ & 607 \\
\hline
\end{tabular}

the costs of health services and the value of life with the amount of emissions of certain types of gases. The results of these studies, synthesized through unit values of pollution costs by gas types, are presented in Table 9.

However, the values listed in Table 9 are calculated on the basis of average exposure per EU country and do not reflect the difference in GDP per country, as they are calculated on the average of certain EU services. For these reasons, it was necessary to adjust these values to the GDP of Montenegro and its relation with the average GDP of the EU Member States. Considering this circumstance, unit values of pollution costs were corrected, which is shown in Table 10.

Related to the calculated investment costs for the implementation of individual measures, projected gas emission reductions by measures and predetermined unit values of pollution costs, Cost-Benefit Analysis for each of the projected emission reduction measures in Montenegro in the period 2020-2029 has been done. Measure effects are examined per year in the 10-year economic life, i.e. in the period 2020-2029, discounted using the chosen discount rate and expressed in the monetary units' present value. Economic analysis served to identify the following two dynamic performance indicators Net Present Value and Benefit

Table 11. Comparative overview of the economic performance indicators by suggested measures - Cost-Benefit Analysis results.

\begin{tabular}{|c|c|c|c|c|c|c|c|}
\hline Measure & $\begin{array}{c}\text { Investment } \\
\text { costs estimation } \\
\text { (EUR) }\end{array}$ & $\begin{array}{c}\text { Total benefits } \\
\text { (EUR) }\end{array}$ & Rank & $\begin{array}{c}\text { Net Present } \\
\text { Value (EUR) }\end{array}$ & Rang & $\begin{array}{c}\text { Benefit - } \\
\text { Cost Ratio }\end{array}$ & Rank \\
\hline $\begin{array}{c}\text { Construction of a flue desulphurization } \\
\text { system in TPP Pljevlja }\end{array}$ & $24,200,000$ & $140,824,468$ & 1 & $82,562,542$ & 1 & 5.91 & 1 \\
\hline $\begin{array}{c}\text { Construction of a flue denitrification } \\
\text { system in TPP Pljevlja }\end{array}$ & $10,900,000$ & $13,547,872$ & 4 & $2,442,779$ & 3 & 1.52 & 4 \\
\hline $\begin{array}{c}\text { Increase of the alternative fuels use, } \\
\text { new vehicle generations and } \\
\text { electromobility in transport }\end{array}$ & $519,900,000$ & $5,080,452$ & 5 & $-369,044,715$ & 9 & 0.01 \\
\hline $\begin{array}{c}\text { Heating devices replacement and } \\
\text { energy efficiency measures in } \\
\text { individual residential buildings }\end{array}$ & $371,400,000$ & $130,169,488$ & 2 & $-239,472,313$ & 8 & 0.29 & 8 \\
\hline $\begin{array}{c}\text { Construction of long-distance heating } \\
\text { system in Pljevlja }\end{array}$ & $23,000,000$ & $52,580,298$ & 3 & $21,852,785$ & 2 & 2.52 & 3 \\
\hline $\begin{array}{c}\text { Prohibition of harvest residues and } \\
\text { agricultural waste ignition }\end{array}$ & 500,000 & $1,691,036$ & 7 & 803,352 & 4 & 3.23 & 2 \\
\hline $\begin{array}{c}\text { Promotion of the organic agriculture } \\
\text { production and animal waste } \\
\text { management system improvement }\end{array}$ & $10,000,000$ & $3,521,047$ & 6 & $-5,245,105$ & 7 & 0.34 & 7 \\
\hline $\begin{array}{c}\text { Good Agricultural Practices Code for } \\
\text { the ammonia emissions control }\end{array}$ & 500,000 & 580,973 & 8 & 22,557 & 5 & 1.11 & 5 \\
\hline $\begin{array}{c}\text { Prohibition on the use of ammonium } \\
\text { carbonate based plant nutrition agents }\end{array}$ & 500,000 & 580,973 & 9 & 22,557 & 5 & 1.11 \\
\hline
\end{tabular}


Cost Ratio. Both indicators are based on the assumption that all future benefits and costs are discounted at the beginning of the project implementation, at a predetermined discount rate [43].

According to the Cost-Benefit Analysis, Table 11 gives a comparative overview of the economic performance indicators by suggested measures to reduce gas emissions and the ranking of individual measures according to the cost-effectiveness indicators.

Based on data in Table 11, certain conclusions can be drawn about the possible priority, i.e. the order of implementation of the envisaged measures.

\section{Conclusions}

As it can be seen from the results of the economic analysis presented above, the measure of construction of a flue desulphurization system in TTP Pljevlja shows the best economic performance indicators. Its realization significantly reduces $\mathrm{SO}_{2}$ emissions, so the economic effects of this measure are greatest as individual economic benefits, Net Present Value, and individual Benefit Cost Ratio. Implementation of the measure of construction of a flue denitrification system in TTP Pljevlja also has positive economic performance indicators, and its implementation from the point of view of economic analysis is indisputable.

With increase of the alternative fuels use, new vehicle generations and electro mobility in transport measure, the identified economic performance indicators can be misleading to some extent. Namely, while Net Present Value and Benefit Cost Ratio are low (NPV is negative and B/CR is significantly lower than 1), it should be borne in mind that the effects of reducing gas emissions are only one of the positive effects realized by implementing the measure. Namely, this measure implementation results in significant savings in the vehicle operating costs primarily fuel costs, but also other operating costs. The aforementioned has a significant impact on the country's energy efficiency and energy balance, especially given the increasing scarcity of fossil fuel sources in the future. Significant reduction in $\mathrm{CO}_{2}$ emissions should also be pointed out because it leads to achieving significant environmental effects in the climate change context, especially in reducing so-called gas emissions - Greenhouse effect. Complete economic analysis of this measure should certainly include all these effects.

Similar situation is with the measure of heating devices replacement and energy efficiency measures in individual residential buildings. Although the realization of this measure brings other direct economic benefits, economic performance indicators of the measure are worse as they indicate only part of the effects achieved by its realization. It should be borne in mind that the implementation of this measure is primarily for the energy efficiency purpose, where most of the economic savings are achieved. On the other hand, savings for individual households are obvious, so its realization is indisputable.

The implementation of the construction of longdistance heating system measure in Pljevlja shows excellent economic results and according to all economic performance indicators (the second largest NPV), and this measure implementation should be at the top of the priorities. Prohibition of harvest residues and agricultural waste measure does not require large investments but provides potentially very good economic indicators, as it contributes to the reduction of $\mathrm{PM}_{2.5}$ suspended particulates which have a very negative impact on human health. The Benefit-Cost Ratio for this measure is extremely positive and its realization is justified, inasmuch as it is a legal obligation.

Promotion of the organic agriculture production and animal waste management system improvement measure only at first glance shows negative results in our economic analysis. Namely, the assessment of ammonia reduction covers only the second aspect of this measure - the improvement of animal waste management systems. An assessment of the reduction of ammonia emissions for the activity of promoting organic production has not been carried out due to the lack of adequate data to enable this. Given the significant economic contribution of only one part of this measure effects, it is realistic to expect that after a complete quantification of the effects. Furthermore, this measure would show satisfactory economic results. The last two measures have identical economic indicators, given that the same investment and the same individual gas emission reduction effects are envisaged. These measures do not require large investments, their implementation is continuous, and the performed analysis indicated positive economic results for both measures.

Considering economic analysis results that have been done for the proposed set of measures, as well as the fact that almost all the proposed measures are already in various stages of implementation, Montenegro will implement these measures in the future, to the extent in which financial opportunities allow. The proposed set of measures will be included in the updated Air Quality Management Strategy, whose adoption is anticipated in 2021. It is expected that the implementation of these measures will certainly contribute to the reduction of pollutant emissions in Montenegro.

\section{Conflict of Interest}

The authors declare no conflict of interest.

\section{References}

1. HUETE-MORALES M.D., QUESADA-RUBIO J.M., NAVARRETE-ÁLVAREZ E., ROSALES-MORENO M.J., DEL-MORAL-ÁVILA M.J. Air quality analysis in the 
European Union, Polish Journal of Environmental Studies, 26 (3), 1579, 2017.

2. FULLWILER S. Sustainable Finance: Building a more general theory of finance. Brinzagr Institute for Sustainable Prosperity. Working Paper, 106, 2016.

3. ALVARADO R., TOLEDO E. Environmental degradation and economic growth: evidence for a developing country, Environment, Development and Sustainability, 19 (4), 1205, 2017.

4. SPYCHAŁA A., DOMAGALSKA J., ĆWIELĄGDRABEK M., MARCHWIŃSKA-WYRWAE E. Correlation between Length of Life and Exposure to Air Pollution, Polish Journal of Environmental Studies, 29 (2), 1361, 2020.

5. ARCEO E., HANNA R., OLIVA P. Does the effect of pollution on infant mortality differ between developing and developed countries? Evidence from Mexico City, The Economic Journal, 126 (591), 257, 2016.

6. BEATTY T.K., SHIMSHACK J.P. Air pollution and children's respiratory health: a cohort analysis, Journal of Environmental Economics and Management, 67 (1), 39, 2014.

7. LESSMANN C. Spatial inequality and development - Is there an inverted-U relationship?, Journal of Development Economics, 106, 35, 2014.

8. WAGNER M. The role of corporate sustainability performance for economic performance: A firm-level analysis of moderation effects, Ecological Economics, 69 (7), 1553, 2010

9. GOYAL P., RAHMAN Z., KAZMI A.A. Corporate sustainability performance and firm performance research: Literature review and future research agenda. Management Decision, 51 (2), 361, 2013.

10. AMANN M. Costs, benefits and economic impacts of the EU clean air strategy and their implications on innovation and competitiveness, International Institute for Applied Systems Analysis (IIASA), 2017.

11. WANG B. Applying machine-learning methods based on causality analysis to determine air quality in China, Polish Journal of Environmental Studies, 28 (5), 3877, 2019.

12. ROGULSKI M. Using Low-Cost PM Monitors to Detect Local Changes of Air Quality, Polish Journal of Environmental Studies, 27 (4), 1699, 2018.

13. WORLD BANK, INSTITUTE FOR HEALTH METRICS, EVALUATION UNIVERSITY OF WASHINGTON. The Cost of Air Pollution Strengthening the Economic Case for Action, International Bank for Reconstruction and Development, 2016

14. GAO J., YUAN Z., LIU X., XIA X., HUANG X., DONG Z. Improving air pollution control policy in China - A perspective based on cost-benefit analysis, Science of the Total Environment, 543, 307, 2016.

15. CHAE Y., PARK J. Quantifying costs and benefits of integrated environmental strategies of air quality management and greenhouse gas reduction in the Seoul Metropolitan Area, Energy Policy, 39 (9), 5296, 2011.

16. ENKHTSOLMON O., MATSUMOTO T., TSEVEEN E. Cost benefit analysis of air pollution abatement options in the Ger Area, Ulaanbaatar, and health benefits using contingent valuation, International Journal of Environmental Science and Development, 7 (5), 330, 2016.

17. VERONEZ D.V., KULAY L.A., SALDIVA P.H.N., SIMONE G.E.K. A cost-benefit evaluation of the air quality and health impacts in Sao Paulo, Brazil, Journal of Environmental Protection, 3 (09), 1161, 2012
18. CROPPER M.L., GUTTIKUNDA S., JAWAHAR P., LAZRI Z., MALIK K., SONG X.P., YAO X. Applying Benefit-Cost Analysis to Air Pollution Control in the Indian Power Sector, Journal of Benefit-Cost Analysis, 10 (S1), 185, 2019.

19. VOORHEES S.S., SAKAI R., ARAKI S., SATO H., OTSU A. Cost-benefit analysis methods for assessing air pollution control programs in urban environments - a review, Environmental health and preventive medicine, $\mathbf{6}$ (2), 63, 2001.

20. BOLLEN J., VAN DER ZWAAN B., BRINK C., EERENS H. Local air pollution and global climate change: A combined cost-benefit analysis, Resource and Energy Economics, 31 (3), 161, 2009.

21. HOLLAND M. Cost-benefit Analysis of Final Policy Scenarios for the EU Clean Air Package, UN Environment, 2014.

22. EC-EUROPEAN COMMISSION. Directive (EU) 2016/2284 of the European Parliament and of the Council of 14 December 2016 on the Reduction of National Emissions of Certain Atmospheric Pollutants, Amending Directive 2003/35/EC and Repealing Directive 2001/81/ EC, Official Journal of the European Union, 344, 1-31, 2016.

23. EC-EUROPEAN COMMISSION. Guidance for the development of National Air Pollution Control Programs under Directive (EU) 2016/2284 of the European Parliament and of the Council on the reduction of national emissions of certain atmospheric pollutants. Official Journal of the European Union, 77/01, 2019.

24. EC-EUROPEAN COMMISSION. Commission Implementing Decision (EU) 2018/1522 of laying down a common format for national air pollution control programs under Directive (EU) 2016/2284 of the European Parliament and of the Council on the reduction of national emissions of certain atmospheric pollutants, Official Journal of the European Union, 6549, 2018.

25. ENVIRONMENT PROTECTION AGENCY OF MONTENEGRO. Air Quality Index, 2019, Available online: http://www.epa.org.me/vazduh (accessed on 1 December 2019) [In Montenegrin].

26. MINISTRY OF TRANSPORT AND MARITIME AFFAIRS. Information on planned activities for implementation of motor vehicle type-approval system in Montenegro, 2014, Available online: http://www.gov. $\mathrm{me} /$ biblioteka/Informacije?alphabet=lat\&sortDirection $=$ Desc \&pagerIndex $=77 \&$ AccessibilityFontSize $=150$ (accessed on 23 October 2019) [In Montenegrin].

27. WORLD BANK. Biomass-Based Heating in the Western Balkans - A Roadmap for Sustainable Development, 2017, Available online: http://documents.worldbank. org/curated/en/135831542022333083/Biomass-BasedHeating-in-the-Western-Balkans-A-Roadmap-forSustainable-Development (accessed on 27 October 2019).

28. WORLD HEALTH ORGANIZATION. WHO air quality guidelines global update 2005: Report on a Working Group Meeting, Bonn, Germany, 18-20 October 2005, WHO Regional Office for Europe, 2005.

29. KRZYZANOWSKI M. The impact of air pollution on health in Montenegro, WHO, 2016.

30. COLOVIC-DAUL M., KRYZANOWSKI M., KUJUNDZIC O. Air Pollution and Human Health: The Case of the Western Balkans, UN Environment, 2019.

31. EUROPEAN PARLIAMENT. Directive 2010/75/EU of the European Parliament and of the Council of 24 November 2010 on industrial emissions (integrated pollution 
prevention and control), Official Journal of the European Union, L 334, 17-119, 2010.

32. ENVIRONMENT PROTECTION AGENCY OF MONTENEGRO. Industrial Emission Act, Official Gazette of Montenegro, 17/19, 2019, Available online: https://epa.org.me/wp-content/uploads/2019/05/Zakon-oindustrijskim-emisijama.pdf (accessed on 10 November 2019) [In Montenegrin].

33. ENERGY INSTITUTE HRVOJE POZAR. Situation analyses of Montenegrin legal, institutional and financial framework in the field of e-mobility, UNDP, 2019, Available online: https://www.undp.org/content/dam/ montenegro/docs/publications/ee/TCNT/Situation $\% 20$ analyses\%20e-mobility.pdf (accessed on 8 November 2019).

34. ENVIRONMENT PROTECTION AGENCY OF MONTENEGRO. Air Protection Act, Official Gazette of Montenegro, 043/15, 2015 [In Montenegrin].

35. EC-EUROPEAN COMMISSION. Guidance for the development of National Air Pollution Control Programmes under Directive (EU) 2016/2284 of the European Parliament and of the Council on the reduction of national emissions of certain atmospheric pollutants, Official Journal of the European Union, C, 77/01, 2019.

36. MONSTAT. Annual statistics on traffic, storage and connections, 2018, Available online: http://monstat. org/userfiles/file/saobracaj/2018/PUBLIKACIJA\%20 GODISNJA\%20STATISTIKA\%20SAOBRACAJA $\% 20$ 2018-cg.pdf (accessed on 3 November 2019) [In Montenegrin].

37. MINISTRY OF SUSTAINABLE DEVELOPMENT AND TOURISM. Montenegro: Second Biennial Update Report on Climate Change, UNDP, 2019, Available online: https://www4.unfccc.int/sites/SubmissionsStaging/ NationalReports/Documents/5937861_Montenegro-
BUR2-1-SECOND\%20BIENNIAL\%20UPDATE\%20 REPORT\%20ON\%20CLIMATE\%20CHANGE_ Montenegro.pdf (accessed on 8 November 2019).

38. MINISTRY OF SUSTAINABLE DEVELOPMENT AND TOURISM. Opinion on a draft of local municipalities study, Official Gazette of Montenegro, 39/16, 2016 [In Montenegrin].

39. MINISTRY OF AGRICULTURE AND RURAL DEVELOPMENT. Regulation on the Conditions, Method and Dynamics of Implementation of Agricultural Policy Measures for 2019 - Agrobudget, Official Gazette of Montenegro, 06/19, 2019 [In Montenegrin].

40. MINISTRY OF AGRICULTURE AND RURAL DEVELOPMENT. Agriculture and Rural Development Program under IPA II Program 2014-2020, 2015, Available online: http://www.ipard.gov.me/ResourceManager/ FileDownload.aspx?rId=365485\&rType $=2 \quad$ (accessed on 11 November 2019) [In Montenegrin].

41. HOLLAND M., PYE S., WATKISS P., DROSTEFRANKE B., BICKEL P. Damages per tonne of PM2,5, $\mathrm{NH}_{3}, \mathrm{SO}_{2}, \mathrm{NOx}$ and VOC's of EU25 Member State (excluding Cyprus) and surrounding seas Service Contract for carrying out cost-benefit analysis of air-quality related issues, in particular in the clean air for Europe (CAFE) programme, European Commission DG Environment, 2010.

42. KORZHENEVYCH A., DEHNEN N., BROECKER J., HOLTKAMP M., MEIER H., GIBSON G., VARMA A., COX V. Update of the handbook on external costs of transport: final report for the European Commission: DGMOVE, 2014.

43. SARTORI D. Guide to cost-benefit analysis of investment projects: Economic appraisal tool for Cohesion policy 2014-2020, European Commission, 2015. 
